MEJUAJUA: Jurnal Pengabdian pada Masyarakat
https://www.jurnal.yaspenosumatera.org/index.php/mejuajua
Volume 1| Nomor 2 | Desember |2021|Hal. 36-41
e-ISSN: 2807-2634

\title{
PKM di Sekolah Menengah Kejuruan Dr.Cipto Mongun Kusumo Kelurahan Perdagangan I Kecamatan Bandar Kabupaten Simalungun Provinsi Sumatera Utara
}

\author{
Ahmad Sumantri ${ }^{1)}$, Suprianto ${ }^{2)}$, Muhammad Rusdi'), Muhammad Fadlan Siregar ${ }^{3)}$, Imam Rangga Bakti \\ 4),Yola Permata Bunda ${ }^{5)}$ \\ ${ }^{\mathbf{1} J u r u s a n}$ Teknik Sipil , Politeknik Negeri Medan, ${ }^{\mathbf{2} J u r u s a n}$ Teknik Elektro , Politeknik Negeri Medan , ${ }^{\mathbf{3} J u r u s a n}$ \\ Teknik Elektro, Universitas Tjut Nyak Dhien, ${ }^{4}$ Jurusan Teknik Informatika, Universitas Pasir Pengaraian, \\ ${ }^{5}$ Jurusan Sistem Informasi, Universitas Tjut Nyak Dhien
}

Keywords :

Pengabdian; google meet;

bandicam

Corespondensi Author

Email: :

suprianto@polmed.ac.id

History Artikel

Received: 08-12-2021

Reviewed: $13-12-2021$

Revised: $12-12-2021$

Accepted: 12-12-2021

Published: 20-12-2021

DOI:

10.52622/mejuajuajabdimas.v1i2.20

\section{Abstrak.}

Program Pengabdian Kemitraan Masyarakat yang dilaksanankan di Sekolah Menengah Kejuruan Dr.Cipto Mangun Kusumo merupakan bagian dari kegiatan rutin pengabdian masyarakat Politeknik Negeri Medan. Tujuan dilaksanakan pengabdian adalah untuk memberikan sumbangan dalam bentuk peralatan berupa Lcd proyektor dan pelatihan kepada guru-guru sekolah Dr.Cipto Mangun Kusumo tentang cara pembuatan video pembelajaran menggunakan bandi cam yang dikombinasikan dengan power point dan penggunaan aplikasi meeting google meet dan zoom. Target khusus yang ingin dicapai adalah para guru dapat membuat video pembelajaran sederhana dan dapat menggunakan aplikasi meeting menggunakan google meet dan zoom baik sebagai host maupun partisipan dan diharapkan setelah pelatihan para guru yang mengikuti pelatihan dapat membagikan ilmunya kepada para guru lainnya atau rekan sejawat yang tidak mengikuti pelatihan. Metode yang akan digunakan untuk mencapai tujuan tersebut adalah metode tatap muka terbatas yang selalu menerapkan protokol kesehatan sekaligus metode penugasan kepada peserta pelatihan. Kegiatan yang dilakukan adalah memberikan materi pelatihan sesuai dengan buku panduan yang dibuat sebelumnya oleh tim pengabdian dan mempraktekannya langsung terhadap sesama peserta pelatihan. Kegiatan berlangsung selama satu hari pada tanggal 3 Desember 2021 yang diikuti oleh 18 guru. Dari hasil pengamatan kegiatan dan wawancara kepada guru diperoleh kesimpulan bahwa terbatasnya jumlah Lcd Proyektor untuk kebutuhan proses belajar mengajar membuat para guru enggan mempersiapkan materi pembelajaran dalam bentuk video pembelajaran yang inovatif, dan penggunaan aplikasi meeting menggunakan google meet lebih diminati oleh guru karena aplikasi tersebut gratis dan mudah digunakan serta durasi meeting tidak dibatasi. Sedangkan penggunaan video pembelajaran menggunakan bandicam baik digunakan dalam pembelajaran luring dan daring, untuk pembelajaran luring dengan pertemuan tatap muka terbatas maka video pembelajaran 
menggunakan bandicam menjadikan proses belajar mengajar lebih efektif karena guru hanya menjelaskan ulang hal-hal penting dan yang menjadi pertanyaan peserta didik sehingga waktu yang digunakan cukup efektif dan peserta didik mempunyai dokumen file rekaman guru ketika menerangkan materi pembelajaran

This work is licensed under a Creative Commons Attribution 4.0 International License

\section{PENDAHULUAN}

Pada masa pandemi segala sesuatu yang berkaitan dengan kerumunan sudah jelas dibatasi melalui peraturan-peraturan dan kebijakan pemerintah terkait pencegahan penularan virus covid 19 termasuk kegiatan tatap muka di sekolah maupun perguruan tinggi.Pada era pandemi kebijakan pendidikan menyesuaikan kondisi kesehatan masyarakat terhadap ancaman virus covid 19, untuk itu cara pembelajaran daring merupakan satu-satunya pilihan yang diterapkan, beberapa aplikasi yang paling sering digunakan adalah Zoom, Google Meet, Google Classroom, dan WhatsApp.(Mannong, 2020). Dukungan teknis dan kualitas jaringan di setiap daerah tentunya tidak sama dalam hal pembelajaran daring untuk itu pengabdian masyarakat termasuk tim PKM Politeknik Negeri Medan kegiatan pengabdian untuk mendukung pelaksanaan pembelajaran daring. Penggunaan google meet sebagai media pembelajaran yang dikombinasikan dengan diskusi dan presentasi menggunakan kemampuan dan skil berbicara dalam menjelaskan permasalahan baik dalam bahasa indonesia dan bahasa inggris menjadi hal yang menjadi nilai tambah dalam kegiatan pembelajaran daring (Afief Fakhruddin., 2019).Guru dalam kegiatan pembelajaran masih jarang yang menggunakan media pembelajaran berupa audio visual maupun video dengan aplikasi bandicam dalam menjelaskan materi pembelajaran karena itu setelah diterapkan aplikasi bandicam dalam pembuatan video pembelajaran maka terjadi perbaikan dalam sistem pembelajaran dengan terjadinya suasana pembelajaran yang efektif dan menarik.(Herayanti, 2019).

Wawancara yang telah dilakukan Tim PKM Dosen Politeknik Negeri Medan dengan Kepala Sekolah ketika survey di lokasi SMK Dr. Cipto Mangun Kusumo telah diketahui bahwa terdapat beberapa permasalahan mitra diantaranya para guru tidak leluasa dalam menyampaikan materi karena penggunaan media pembelajaran daring yang digunakan hanya terbatas pada google classroom dan wa group sehingga menyebabkan kejenuhan/kebosanan para guru dan siswa dalam proses belajar mengajar.kemudian guru membutuhkan pelatihan cara pembelajaran daring yang lain sebagai tambahan selain google classroom yang mudah dipahami, menarik dan tidak berbayar perangkat lunaknya.Penggunaan google meeet lebih banyak diminati oleh dunia pendidikan dan dunia bisnis, banyak rapat dalam kegiatan bisnis menggunakan google meet demikian rapat-rapat organisasi masyarakat, sekolah dan lain-lain disebabkan oleh penggunaan google meet mudah, gratis dan tidak dibatasi oleh penggunaan lamanya waktu meeting (Purwanto,2020). Kegiatan tim PKM berlangsung selama satu hari pada tanggal 3 Desember 2021 yang diikuti oleh 18 guru dan diantaranya adalah pelatihan dengan menggunakan google meet karena metode ceramah dengan dibantu oleh media Google Meet memiliki pengaruh yang signifikan dalam membangun pengetahuan dan hasil belajar siswa dalam masa pandemi (Setyawan,2020). Tujuan dilaksanakan pengabdian adalah untuk memberikan sumbangan dalam bentuk peralatan berupa Lcd proyektor dan pelatihan kepada guru-guru sekolah Dr.Cipto Mangun Kusumo tentang cara pembuatan video pembelajaran menggunakan bandi cam yang dikombinasikan dengan power point dan penggunaan aplikasi meeting google meet dan zoom. Pelatihan penggunaan video pembelajaran yang dibuat dengan menggunakan bandi cam membuat para guru lebih leluasa dalam menyampaikan materi secara jelas ditambah dengan conference/meeting menggunakan aplikasi google meet membuat siswa lebih tertarik mengikuti materi pembelajaran.

Sementara itu penggunaan video pembelajaran menggunakan bandi cam yang dipadukan dalam powerpoint dapat menghilangkan kejenuhan guru dan siswa dalam proses belajar mengajar dimana seolah-olah guru dengan wajah dan gerakan mengajarnya tampil secara live pada samping papan tulis virtual . 


\section{METODE}

Metode Pelaksanaan kegiatan Pengabdian Kemitraan Masyarakat atau langkah-langkah dalam melaksanakan solusi yang ditawarkan dibuat dalam bentuk flowchart berikut:

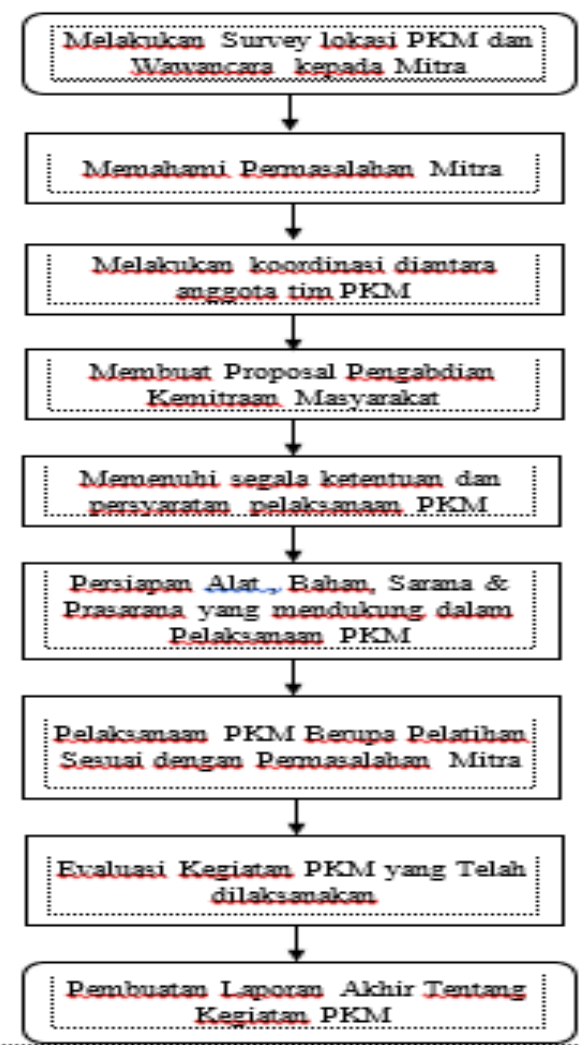

Gambar 1. Diagram Alir Pelaksanaan Kegiatan Pengabdian Kemitraan Masyarakat

Penjelasan mengenai tahapan atau langkah-langkah yang ditempuh guna melaksanakan solusi atas permasalahan yang dihadapi oleh mitra adalah sebagai berikut :

Tahap 1. Melakukan Survey lokasi PKM tepatnya di Jl. Karya Bakti kelurahan Perdagangan I kecamatan Bandar Kabupaten Simalungun dan Wawancara sekaligus silaturrahmi kepada Mitra dalam hal ini adalah Kepala Sekolah Bapak Fazli Almaulana S.Pd.,M.Pd. dan beberapa guru yang mendampinginya.

Tahap 2. Kegiatan silaturrahmi dan wawancara yang dilakukan beralih kemudian kepada pembicaraan tentang permasalahan yang dihadapi mitra saat ini yaitu beberapa permasalahan diantaranya mengenai peningkatan kemampuan dan inovasi guru-guru dalam pembelajaran daring melalui kegiatan pelatihan

Tahap 3. Melakukan koordinasi diantara sesama anggota tim PKM Polmed untuk meninjau kelayakan pelaksanaan program PKM di tempat mitra nantinya dan sekaligus memperhitungkan dan merencanakan pelaksanaan pengabdian nantinya bila usulan pengabdian disetujui.

Tahap 4. Membuat Proposal Pengabdian Kemitraan Masyarakat yang ditujukan ke P3M Polmed agar instansi mengetahui sekaligus menilai apakah kegiatan PKM yang akan dilakukan layak atau tidak layak berdasarkan penilaian dari korektor.

Tahap 5. Memenuhi segala ketentuan dan persyaratan pelaksanaan PKM yang berarti P3M Polmed berhak penuh menggagalkan kegiatan PKM atau sebaliknya yaitu mendukung sepenuhnya kegiatan tersebut dengan pembiayaan yang ditentukan dan melakukan pejanjian tentang kegiatan PKM dari kedua pihak yaitu P3M Polmed dan tim Pengabdian Kemitraan Masyarakat

Tahap 6. Mempersiapkan peralatan, sarana dan prasarana yang dimaksudkan untuk menunjang 
kegiatan PKM misalnya persiapan gedung yang memiliki jaringan internet khusus atau paket data internet yang cukup agar peserta pelatihan tidak mengalami kesulitan saat pelatihan berlangsung.

Tahap 7. Pelaksanaan PKM selama 1 hari dan merupakan kegiatan inti dari PKM yaitu berupa pelatihan video pembelajaran dan aplikasi meeting yang diikuti oleh 18 orang peserta dengan menerapkan protokol kesehatan, menjaga jarak, mencuci tangan dan memakai masker dan dalam kegiatan pelatihan tersebut terdapat solusi solusi yang ditawarkan untuk menjawab permasalahan yang dihadapi mitra.

Tahap 8. Mengevaluasi kegiatan PKM yang telah dilaksanakan apakah sesuai target luaran yang direncanakan sebelumnya atau sebaliknya.

Tahap 9. Pembuatan Laporan Akhir tentang Kegiatan PKM sesuai yang terdapat di dalam ketentuan dan persyaratan yang diberlakukan oleh P3M Polmed

Partisipasi mitra dalam pelaksanaan program pelatihan dalam rangka kegiatan PKM adalah menyediakan peserta pelatihan yang berasal dari guru sekolah SMK Dr.Cipto Mangun Kusumo sebanyak 18 orang, membantu dan bekerjasama untuk urusan administrasi berkaitan dengan prosedur dan ketentuan pelaksanaan PKM serta partisipasi pihak mitra yang sangat membantu dalam menyiapkan dan menyediakan ruangan khusus yang mendukung protokol kesehatan dalam menjaga jarak dan dapat dengan mudah mengakses jaringan internet dari dalam ruangan tersebut. keberlanjutan program setelah selesai kegiatan PKM bagi mitra adalah menerapkan ilmu yang didapat selama pelatihan untuk kemudian diaplikasikan dalam proses belajar mengajar sebagai wujud dari pembelajaran daring pada masa pandemi covid 19 yang variatif dan inovatif sehingga dapat meningkatkan kualitas pembelajaran daring dan dapat meningkattkan partisipasi siswa dalam mengerjakan tugas-tugas karena lebih menarik dan mudah dipahami

\section{HASIL DAN PEMBAHASAN}

koordinasi diantara sesama anggota tim PKM Polmed untuk melaksanakan program PKM di tempat mitra merupakan hal yang rutin dilakukan pada setiap kegiatan PKM, semua persiapan mulai dari pendanaan untuk keberangkatan pengabdian, uji coba peralatan yang diberikan, persiapan modul pelatihan, pembagian tugas pelaksanaan pengabdian, konsumsi, dan persiapan sarana dan prasarana dalam kegiatan pengabdian telah dipersiapkan sebelumnya secara matang agar kegiatan dapat berjalan dengan baik dan lancar. Pelaksanaan PKM berlangsung selama 1 hari mulai dari perjalanan ke tempat mitra hingga sampai pada lokasi yang dituju dengan lama perjalanan kurang lebih selama 2 jam perjalanan, dalam kegiatan selama 1 hari tersebut termasuk silaturahmi dan perkenalan singkat kepada mitra dan penyerahan batuan peralatan berupa LCD Proyektor yang diberikan secara gratis kepada mitra untuk menunjang proses belajar mengajar di tempat mitra. Dan kemudian dilaksanakan kegiatan inti tim PKM yaitu berupa pelatihan yang terdiri dari pelatihan tentang aplikasi meeting yang berupa zoom dan google meet serta pelatihan merancang video pembelajaran menggunakan aplikasi bandicam. Pelatihan video pembelajaran dan aplikasi meeting diikuti oleh 18 orang peserta guru dan berlangsung dengan baik dan lancar. Peserta pelatihan cukup serius mengikuti kegiatan ini hingga sesi tanya jawab berlangsung lama dan serius pada setiap bagian materi pelatihan, beragam pertanyaan diajukan oleh peserta pelatihan termasuk permasalahan yang dihadapi ketika menggunakan aplikasi meeting dan video pembelajaran.

Setelah selesainya kegiatan pelatihan Tim PKM dengan berkoordinasi dengan kepala sekolah bekerjasama untuk melakukan penugasan kepada guru tentang materi pelatihan yang sudah dilakukan. Berdasarkan hasil penugasan yang diberikan kepada 18 peserta pelatihan semuanya sudah berhasil dengan baik melaksanakan penugasan hanya saja sebagian terkendala dengan camera handphone guru yang mengalami masalah sistem kamera handphonenya terkait tentang materi pelatihan. Pada dasarnya semua guru yang mengikuti pelatihan sudah mampu menggunakan aplikasi meeting baik sebagai host maupun sebagai partisipan untuk aplikasi zoom dan google meet demikian juga dalam pembuatan video pembelajaran menggunakan bandicam para guru sudah mencoba dan mengaplikasikan tampilan video guru pada video pembelajaran. Hal-hal yang menjadi permasalahan dalam kegiatan ini adalah koneksi jaringan internet yang terkadang kurang stabil dan adanya beberapa guru yang kurang percaya diri dalam 
mencoba berbagai fitur dan fasilitas yang ditampilkan pada menu video pembelajaran dan aplikasi meeting. Pada saat sebelum dilaksanakan pengabdian frekuensi penggunaan LCD Proyektor masih kurang bila dibandingkan dengan setelah dilaksanakan kegiatan pengabdian oleh tim PKM Politeknik Negeri Medan.

Demikian juga penggunaan video pembelajaran setelah diadakannya kegiatan pengabdian beberapa guru sudah berusaha mencoba pelaksanaan pengajaran dengan menggunakan video pembelajaran.

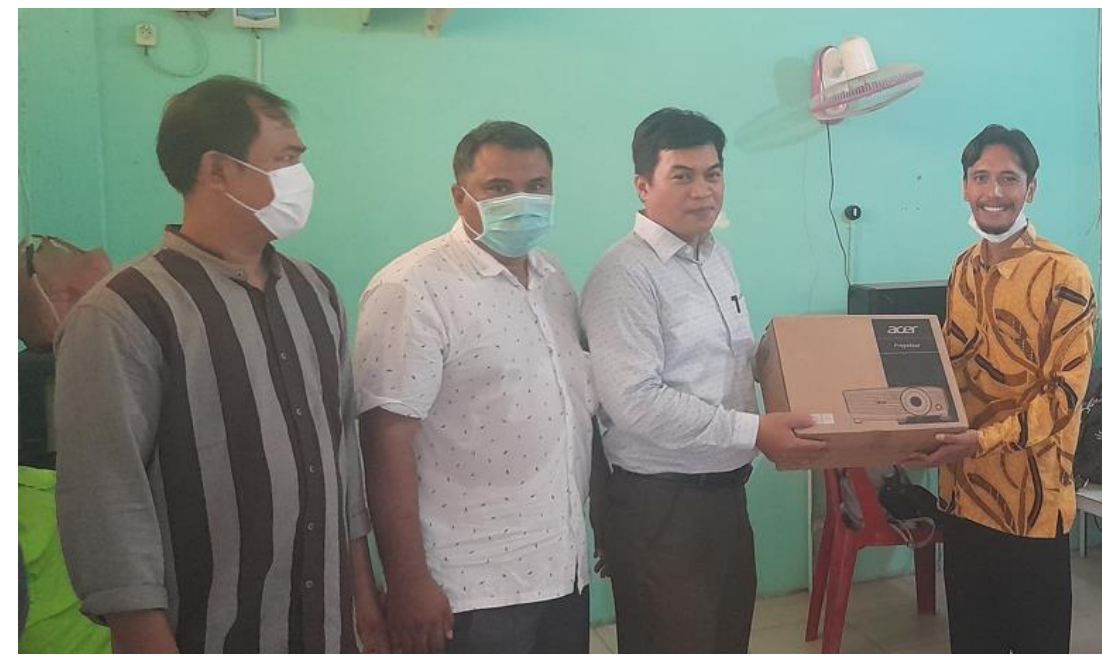

Gambar 2. Tim PKM Politeknik Negeri Medan Memberikan Lcd Proyektor kepada kepala sekolah SMK Dr. Cipto Mangun Kusumo Perdagangan

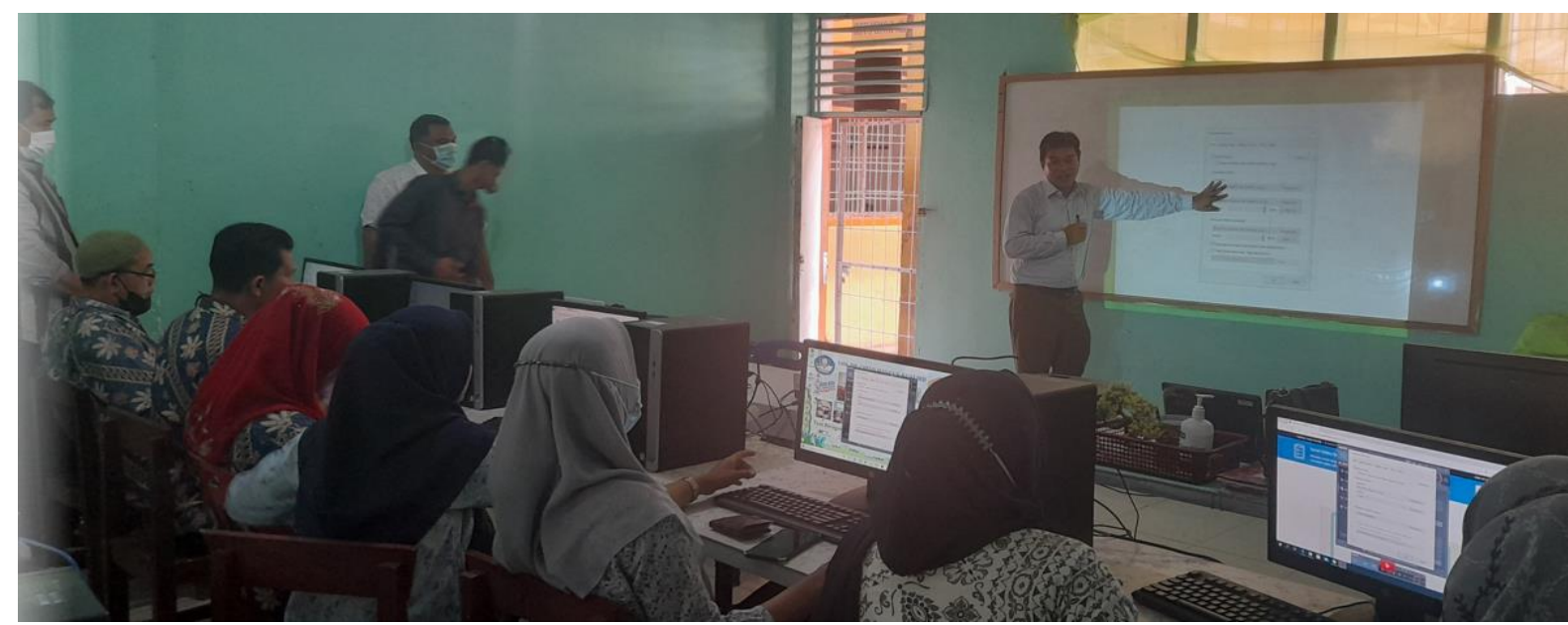

Gambar 3. Tim PKM Politeknik Negeri Medan Memberikan pelatihan kepada para guru tentang aplikasi meeting dan video pembelajaran

\section{KESIMPULAN}

Terbatasnya jumlah Lcd Proyektor untuk kebutuhan proses belajar mengajar membuat para guru enggan mempersiapkan materi pembelajaran dalam bentuk video pembelajaran yang inovatif, dengan adanya pemberian Lcd Proyektor oleh tim PKM Politeknik Negeri Medan maka akan menambah jumlah Lcd Proyektor yang sudah ada dan dapat dimanfaatkan untuk proses belajar mengajar, penggunaan aplikasi meeting menggunakan google meet lebih diminati oleh guru karena aplikasi tersebut gratis dan mudah digunakan serta durasi meeting tidak dibatasi. Penggunaan video pembelajaran menggunakan bandicam baik digunakan dalam pembelajaran luring dan daring, untuk pembelajaran luring dengan PTM video pembelajaran menggunakan bandicam menjadikan proses belajar mengajar lebih efektif karena guru hanya menjelaskan ulang hal-hal penting dan yang menjadi 
pertanyaan peserta didik sehingga waktu yang digunakan cukup efektif dan peserta didik mempunyai dokumen file rekaman guru ketika menerangkan materi pembelajaran. Google classroom dan wa group tetap digunakan oleh SMK Dr.Cipto Mangun Kusumo Perdagangan dan dikombinasikan penggunaannya dengan aplikasi meeting berupa google meet dan video pembelajaran menggunakan bandicam. Disarankan sebaiknya pelaksanaan kegiataan pengabdian diizinkan untuk dapat dilakukan paling tidak dua tahun berturut-turut agar terjadi hubungan yang erat dan harmonis dengan mitra serta memungkinkan banyak kegiatan yang dapat menyelesaikan permasalahan mitra dengan lebih komprehensip

\section{DAFTAR RUJUKAN}

1. Afief Fakhruddin.. Using Google Meet in Teaching Speaking. In Journal of English Language Learning (JELL) (Vol. 2, Issue 2, pp. 43-46), 2019.

2. Herayanti, L., \& Safitri, B. R. A. Pembelajaran Mendesain Rumah Menggunakan Media Audio Visual Dengan Memanfaatkan Bandicam. In Jurnal Pendidikan Fisika dan Teknologi (Vol. 5, Issue 2, p. 305). https://doi.org/10.29303/jpft.v5i2.1429, 2019

3. Mannong, A. B. M. the Students' Eyesight: the Effectiveness of Learning-Based Applications on Elt in Pandemic Era. In ETERNAL (English, Teaching, Learning, and Research Journal) (Vol. 6, Issue 2, p. 394). https://doi.org/10.24252/eternal.v62.2020.a14, 2020

4. Purwanto, E., \& Tannady, H. The Factors Affecting Intention to Use Google Meet Amid Online Meeting Platforms Competition in Indonesia. In Technology Reports of Kansai University Vol. 62, Issue 06, pp. 2829-2838., 2020.

5. Setyawan, A., Aznam, N., Paidi, Citrawati, T., \& Kusdianto. Effects of the Google meet assisted method of learning on building student knowledge and learning outcomes. In Universal Journal of Educational Research (Vol. 8, Issue 9, pp. 3924-3936). https://doi.org/10.13189/ujer.2020.080917., 2020 